\title{
610 コンクリート 2 次製品用龬製型伜の強度設計および軽量化に関する研究 \\ Study on an intensity design and weight saving of the steel form for secondary concrete products
}

\author{
正 新谷 真功(福井大) $\bigcirc$ 学 奥野 遼司(福井大院) \\ 田中 允忠(有限会社ティシィディ)
}

MASANORI SHINTANI, Graduate School of Engineering, University of Fukui RYOJI OKUNO, Graduate Student School of Engineering, University of Fukui YOSHITADA TANAKA, TCD Ltd.

\begin{abstract}
This paper deals with strength design and motional analysis of a machine structure by 3D Computer Aided Design (3DCAD) and Computer Aided Engineering (CAE). Cost, rigidity, etc. are raised as a point that should be taken into consideration in designing a machine structure. Holding down productive energy and cost low relates to earth environment in that resources are utilized effectively. This research examines the improved model using 3DCAD and motional analysis.
\end{abstract}

Key Words: 3DCAD,CAE, Steel form, Finite element method

\section{A1. 粕会}

本研究の対象は，図 A1 に示すコンクリート 2 次製品用 鋼製型枠であり，型枠は長年使い続けられることで，型枠 の負担となり耐用年数に達する. また, 現在は過去の経験 測で型枠の設計を行っているため, 合理的な設計でなく, 軽量化の余地がある.そこで，本研究の目的は，コンクリ 一ト製品製造時に生じる変位量・相当応力の低減できる新 構造の提案を行うことで耐用年数向上を図り，同時に重量 $20 \%$ 低減することである. まず，型枠の $3 \mathrm{D}$ 解析モデルを 作成し，CAE 解析を行っている. 次に, 従来型枠にて製品 製造時の変位量・相当応力などの測定実験を行い, 解析結 果と実験結果の比較を行うことで, 解析モデルの有効性を 検討している，そして，新構造の解析モデルを作成し，現 モデルとの比較を行うことで, 新構造モデルの有効性を検 討している.

\section{A2. 解析および实験}

本研究の解析対象となる銅製型枠のモデルを作成した. その組立てモデルを図 A2 に示す. 本解析では, コンクリ 一ト製品製造時に型枠に生じる変位量・相当応力の解析を 行った．解析モデルの有効性を示すために，実際の鋼製型 枠にコンクリートを流し込む実験を行った，まず，鋼製型 枠に生コンクリートを流し込んだ状態にて，ひずみ測定を 行い, 応力を求めた。 また, 生コンクリート流し込み完了 後に，ダイアルゲージにて変位量を読み取った. 表 $\mathrm{Al} よ$ り解析と実験結果はほぼ一致しており，解析モデルの有効 性を示した。

\section{A3. 改善案モデルの検討}

従来型枠は下部のベースを $150 \mathrm{~mm}$ と $200 \mathrm{~mm}$ のC型チャ ンネルで構成しているのに対し, 新構造型枠は $250 \times$ $250 \mathrm{~mm}$ の角パイプで構成している. また, 従来型枠の主強 度鋼材のベースは L 鋼で構成しているのに対し, 新構造型 枠は $200 \times 100 \mathrm{~mm}$ の角パイプで構成している.さらに，従 来型枠は主強度鎆材を補強するリブを多用しているのに対 し，新構造型枠は角パイプの使用により主強度鋼材の強度
向上が見込まれるため, リブの数が少ない．これら従来型 枠からの設計変更により, 最大変位量は $1.21 \mathrm{~mm}$ から $1.07 \mathrm{~mm}$, 相当応力は $182 \mathrm{MPa}$ から $60.5 \mathrm{MPa}$, 重量は $3100 \mathrm{~kg}$ から $2440 \mathrm{~kg}$ (22\%低減)に低減していることが確認できた.

\section{A4. 結言}

1) 型枠の 3D 解析モデルを作成し, CAE 解析を行った.

2) 解析結果と実験結果はほぼ一致しており, 鋼製型枠の 解析モデルは有効であると思われる.

3）実験を行い,ひずみ・変位量を測定した.

4) 従来型枠と新構造型枠の解析結果の比較から, 新構造 型枠は変位量・相当応力の低減および重量 20\%低減を 達成できた。

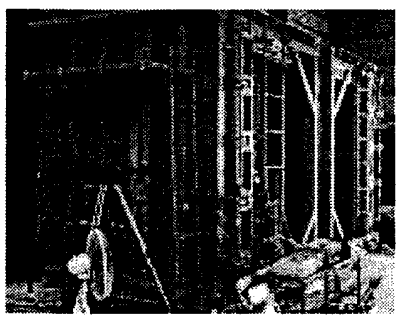

Fig.Al Steel form

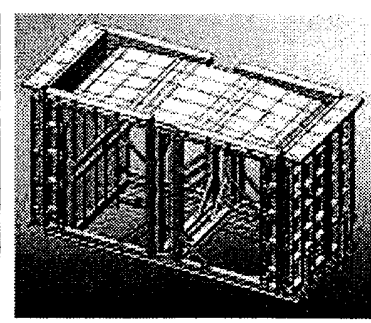

Fig.A2 Model figure
Table Al Comparison between experimental results and analytical results

\begin{tabular}{|c||c|c|c|}
\hline & $\begin{array}{c}\text { Measurement } \\
\text { location number }\end{array}$ & $\begin{array}{c}\text { Experimental } \\
\text { result }\end{array}$ & $\begin{array}{c}\text { Analytical } \\
\text { result }\end{array}$ \\
\hline \hline \multirow{4}{*}{$\begin{array}{c}\text { Displacement } \\
(\mathrm{mm})\end{array}$} & $\mathrm{A}$ & 1.83 & 1.50 \\
\cline { 2 - 4 } & $\mathrm{B}$ & 0.80 & 0.80 \\
\hline \hline \multirow{3}{*}{$\begin{array}{c}\text { Von mises } \\
\text { stress (MPa) }\end{array}$} & $\mathrm{C}$ & 0.08 & 0.10 \\
\cline { 2 - 4 } & $\mathrm{C}$ & 6.70 & 7.57 \\
\cline { 2 - 4 } & (1) & 6.05 & 5.00 \\
\hline
\end{tabular}

日本機械学会〔No.09-23〕Dynamics and Design Conference 2009 CD-ROM 論文集〔2009.8.3-8,札幌〕 


\section{1. 楮言}

現在，コンクリート 2 次製品用鋼製型枠は，コンクリー 卜 2 次製品メーカーにおいて，道路・擁壁・河川・鉄道・ 下水道などのコンクリート製品製造用として使用されてい る. 型枠の形状，寸法などは，その使用目的により多種多 岐にわたっており，のべ数万種類にものぼっている．本研 究の対象となるのは, 道路工事に用いられている道路用 L 型擁壁を製造するための鋼製型枠である，推壁は，鋼製型 枠に生コンクリートを流し込み，加振器で振動を与えなが ら成型され製造されている，その時発生する生コンクリー トによる圧力や, 加振器による加振力が, 長年型枠に加え 続けられることで, 型枠の負担となっている. また, 現在 は過去の経験測で型枠の設計を行っているため, 合理的な 設計でなく，軽量化の余地がある.

そこで本研究は, 生コンクリートによる圧力や, 加振器 による加振力によって型枠に生じる変位量・相当応力の低 减できる新構造の提案を行い，同時に重量 20\%低減を目的 としている. しかし，型枠の負担低減と軽量化について検 討する場合，実際に新構造の型枠を製作し，その有効性を 示す方法では，時間とコストが莫大にかかり，実現が困難 であると考えられる.そこで, 3DCAD ソフト SolidWorks 及びCAEソフトANSYS DesignSpace を用いて, 生コンク リートを流し込んだ際に型枠に生じる変位量・相当态力の 状態を再現し，その解析值と実際に測定した実験值とを比 較・検討し, 解析の有効性を示すことにより, 3DCAD・CAE を用いて新構造の検討を行っている. 道路用 L 型擁壁を図 1 に，本研究の対象鋼製型枠を図 2 に示す.

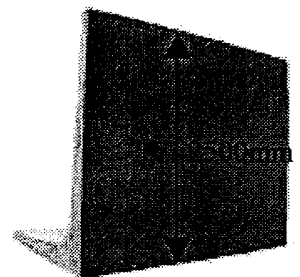

Fig.1 L type wall for roads

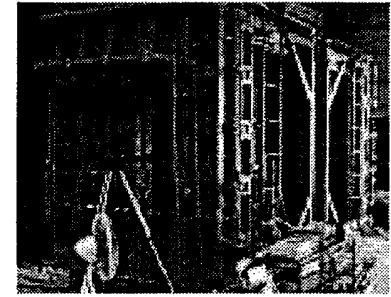

Fig.2 Steel form

\section{2. 銅慜型伜の CAE 解析}

本研究の解析対象となる鋼製型枠のモデルを作成した. その組立てモデルを図 3 に示す. 本解析では, 䤡製型枠に 生コンクリートを流し込んだ際に生じる変位量・相当応力 の解析を行った. 解析条件は, モデルの基礎下部を固定し, 生コンクリートにより鐦製型枠に生じる圧力を計算により 求め, 解析を行った。変位量の解析結果を図 4, 相当応力 の解析結果を図 5 に示す. また, 3 章の 3.2 で実験結果と解 析結果の比較・考察を示している.

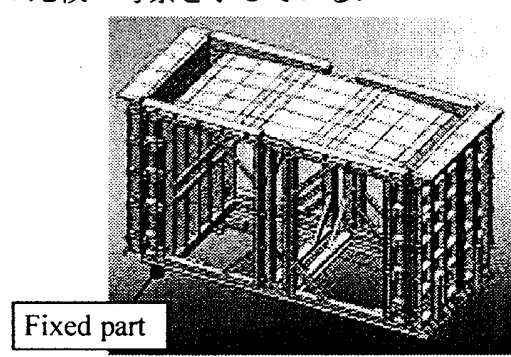

Fig.3 Model figure

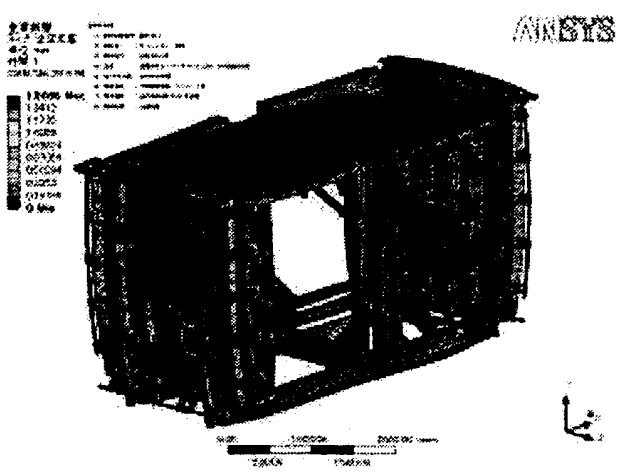

Fig.4 Analytical result of steel (Deformation)

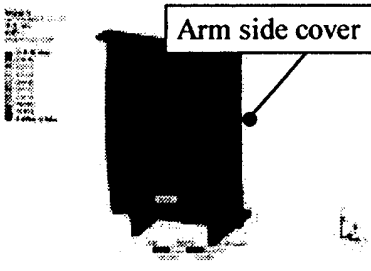

(A)Von mises stress

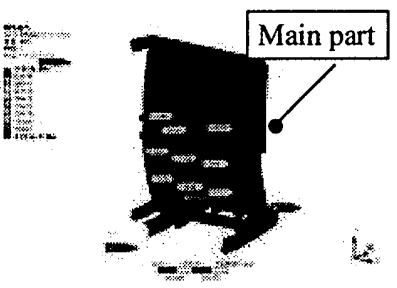

(C)Von mises stress

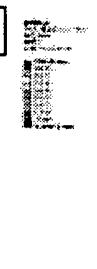

(B) Von mises stress
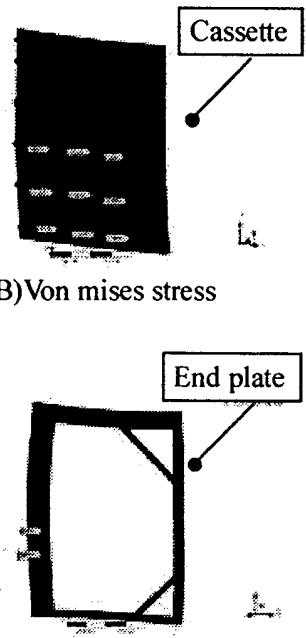

(D) Von mises stress
Fig.5 Analytical result of steel form (A,B,C,D)

\section{3. 英験}

3.1. 実験方法 解析モデルの有効性を示すために, 実際 の鋼製型枠にコンクリートを流し込む実験を行った.まず， 鋼製型枠に生コンクリートを $2500 \mathrm{~mm}$ (流し込み完了) の 高さまで流し込んだ状態にて，それぞれひずみを解析位置 と同様の位置で測定を行い, 相当応力を求めた. また, 生 コンクリート流し込み完了後に, 予め取り付けておいたダ イアルゲージの変位量（3 ヶ所）を読み取った. 測定位置 を図 6 に示す.

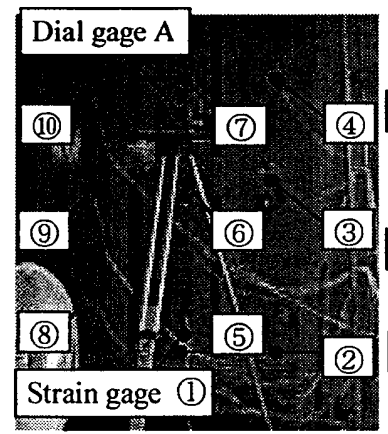

(A)Arm side cover

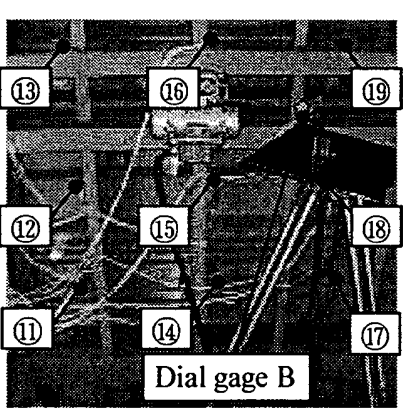

(B)Main part 


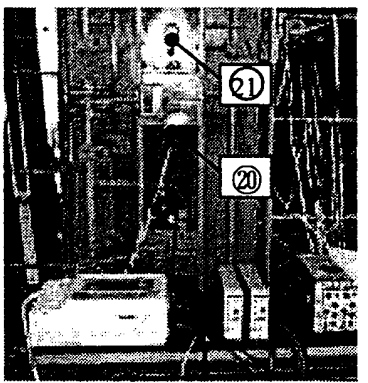

(C)End plate

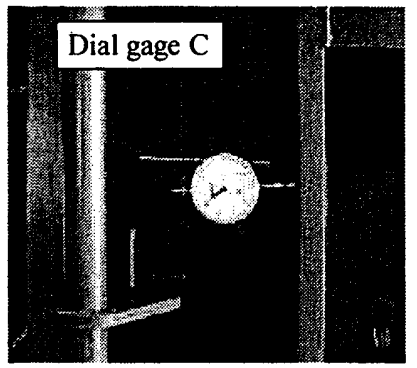

(D)End plate
Fig.6 Displacement, Von mises stress measuring point (A,B,C,D)

3.2. 实跧秸果と解析結果の比較 変位量と相当応力につ いての実験結果と解析結果の比較を行った. その比較を表 1 に示寸. 表 1 に示寸実験結果は, 解析と条件を一致させ るため, 銅製型枠に生コンクリートを高さ $2500 \mathrm{~mm}$ （流し 込み完了）まで流し込んだ状態の実験結果を示している. 表 1 より, 実験結果と解析結果の変位量・相当応力はほぼ 一致している.よって，3DCAD・CAE を用いることで, 生コンクリートを流し込んだ際に鋼製型枠に生じる変位 量・相当态力の状態を再現することができ，本解析は有効 であると思われる.

Table1 Comparison between experimental results and analytical results

\begin{tabular}{|c||c|c|c|}
\hline & $\begin{array}{c}\text { Measurement } \\
\text { location number }\end{array}$ & $\begin{array}{c}\text { Experimental } \\
\text { result }\end{array}$ & $\begin{array}{c}\text { Analytical } \\
\text { result }\end{array}$ \\
\hline \hline \multirow{4}{*}{$\begin{array}{c}\text { Displacement } \\
\text { (mm) }\end{array}$} & $\mathrm{A}$ & 1.83 & 1.50 \\
\cline { 2 - 4 } & $\mathrm{B}$ & 0.80 & 0.80 \\
\hline \hline & $\mathrm{C}$ & 0.08 & 0.10 \\
\hline \multirow{4}{*}{$\begin{array}{c}\text { Von mises } \\
\text { stress (MPa) }\end{array}$} & (1) & 6.70 & 7.57 \\
\cline { 2 - 4 } & (2) & 14.2 & 11.0 \\
\cline { 2 - 4 } & (6) & 6.05 & 5.00 \\
\cline { 2 - 4 } & $(9)$ & 6.91 & 5.02 \\
\cline { 2 - 4 } & (10) & 16.1 & 11.2 \\
\cline { 2 - 4 } & (11) & 12.1 & 9.84 \\
\cline { 2 - 4 } & (16) & 13.45 & 5.20 \\
\hline \multirow{7yy}{*}{$(20)$} & 5.93 & 8.81 \\
\hline
\end{tabular}

\section{4. 新構造型伜の CAE 解析}

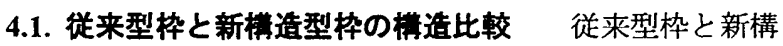
造型枠の断面図を図 7 に示寸。従来型枠は下部のベースを $150 \mathrm{~mm}$ と $200 \mathrm{~mm}$ のC型鋼で構成しているのに対し, 新構 造型枠は $250 \times 250 \mathrm{~mm}$ の角パイプで構成している，また， 従来型枠の主強度銅材のベースは L 銅で構成しているのに 対し, 新構造型枠は $200 \times 100 \mathrm{~mm}$ の角パイプで構成してい る.さらに，従来型枠は主強度銅材を補強するリブを多用 しているのに対し, 新構造型枠は角パイプの使用により主 強度鋼材の強度向上が見込まれるため, リブの数が少ない． これら従来型枠からの設計変更により, 新構造型染の部品
点数は従来型枠の 3 分の 2 と少なく, 型枠の溶接組立て作 業の時間短縮にも慗がると考えられる。

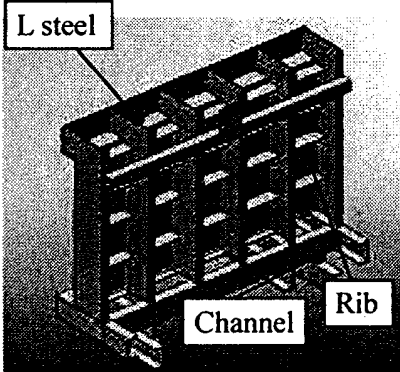

(A)The conventional steel form

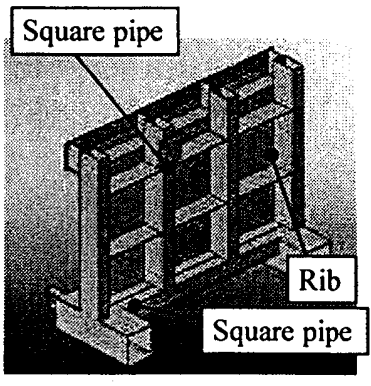

(B)New steel form
Fig.7 Sectional drawing $(A, B)$

4.2. 従来型挅と新權造型枠の解析結果の比较 新構造型 枠の解析を行い, 従来型枠の変位量・相当応力・重量につ いて比較を行うことで, 新構造型枠の有効性を検討した. 解析条件は 2 章と同様とする. 新構造型枠の解析結果を図 8 に示し, 従来型枠と新構造型枠の解析結果の比較を表 2 に示す. 表 2 より, 従来型枠と新構造型枠を比較すると, 変位量は $1.21 \mathrm{~mm}$ から $1.07 \mathrm{~mm}$, 相当応力は $182 \mathrm{MPa}$ から $60.5 \mathrm{MPa}$, 重量は $3100 \mathrm{~kg}$ から $2440 \mathrm{~kg}(22 \%$ 低減)に低減して いる. よってこの新構造型枠は変位量・相当态力の低减抒 よび重量 20\%低減という研究目的を達成しており, 有効だ と考えられる.

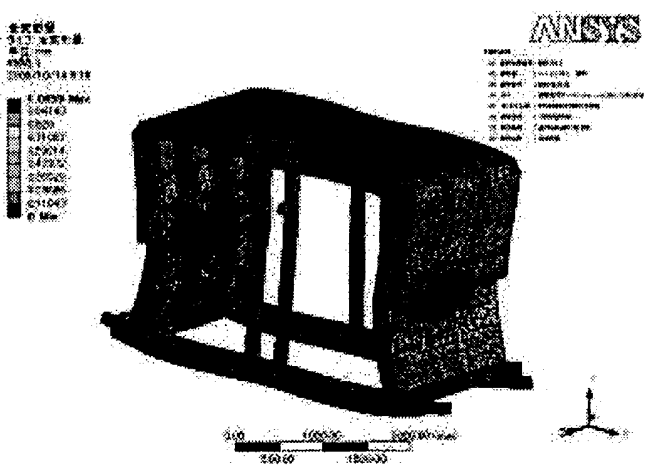

(A)Deformation

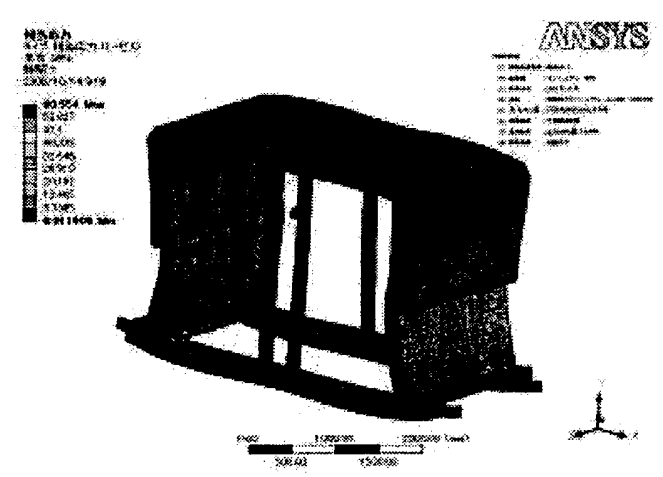

(B) Von mises stress

Fig.8 Analytical result of new steel form (A,B) 
Table2 Comparison between analytical results

\begin{tabular}{|c||c|c|}
\hline \multicolumn{1}{|c|}{} & \multicolumn{2}{c|}{ Analytical result } \\
\cline { 2 - 3 } & $\begin{array}{c}\text { The conventional } \\
\text { steel form }\end{array}$ & New steel form \\
\hline \hline $\begin{array}{c}\text { Max Displacement } \\
(\mathrm{mm})\end{array}$ & 1.21 & 1.07 \\
\hline $\begin{array}{c}\text { Max Von mises stress } \\
\text { (MPa) }\end{array}$ & 182 & 60.5 \\
\hline Weight (kg) & 3100 & 2440 \\
\hline
\end{tabular}

\section{5. 龢裂型枠の周波数応答解析}

\section{1. 鋼製型伜の秎組立てでの周波数応答解析と測定 ב}

ンクリート製品は，その製造時に型枠に取り付けた加振器 を加振させながら生コンクリートを流し込む. しかし, 現 在加振器の取り付け位置は, 過去の経験則だけで決めてい るため，有効な取り付け位置とは言えず，型枠全体に有効 に振動が伝わっているか分かっていない，そこで周波数応 答解析結果と実験による周波数測定結果とを比較・検討す ることで, 加振器の有効な取り付け位置の検討を行うこと とした. 本研究対象となっている型枠は，本体内側に左右 1 個ずつ計 2 個の加振器を取り付け, $120 \mathrm{~Hz}$ で加振される ものである.解析位置および測定位置を図 9 に示す.まず, コンクリート製品製造時における周波数解析モデルを作成 し, 図 9 の位置 A,B,C,D において周波数応答解析を行った. そして，周波数測定実験を解析同様の位置で行い，比較・ 検討を行った．尚，本解析は型枠に $50 \mathrm{~Hz}$ から $500 \mathrm{~Hz}$ まで の周波数を，10 段階に分割し，各周波数でどのような振幅 が得られるかを解析している.

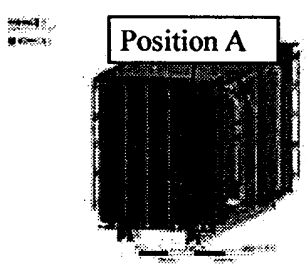

(A)Position A
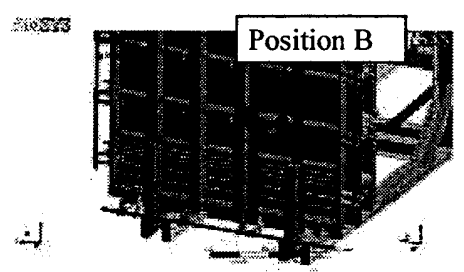

(B) Position B

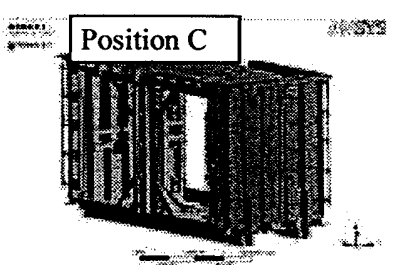

(C)Position C

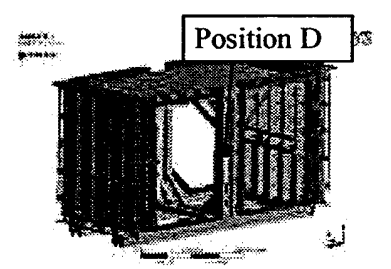

(D) Position D
Fig.9 Analysis and a measurement positions

5.2. 周波数応答解析結果と実験結果の比較 解析結果を 図 10, 測定結果を図 11 に示す. 図 10 の解析結果のいずれ も，100Hz で卓越した周波数となっていることから, $100 \mathrm{~Hz}$ 付近での加振が大きな振幅を得られる有効な周波数と言え る.つまり，現在の $120 \mathrm{~Hz}$ での加振は有効な加振方法であ ると言える.さらに，図 11 の測定結果のいずれも $110 \mathrm{~Hz}$ 近傍で卓越した周波数となっている。 これは，加振時の周 波数 $120 \mathrm{~Hz}$ とほぼ同一数值である.つまり, 現在の加振時 の周波数が型枠の各部に良く伝わっていると思われる。こ
れらのことから, 現在の加振時の周波数は型枠の各部に良 く伝わっており, さらに, 現在の $120 \mathrm{~Hz}$ での加振は大きな 振幅が得られる有効な加振方法であることが分かった。

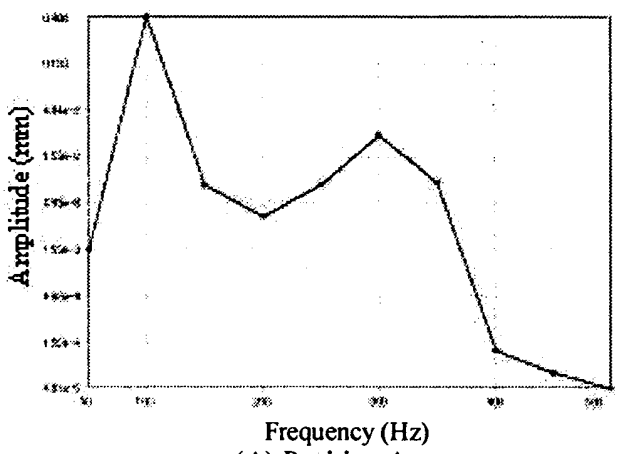

(A) Position A

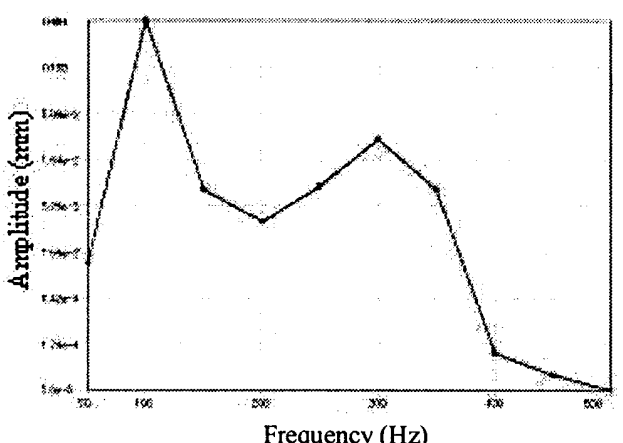

(B) Position $\mathrm{B}$

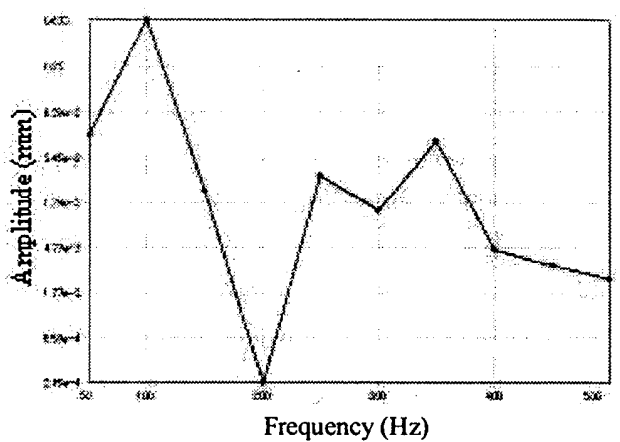

(C) Position C

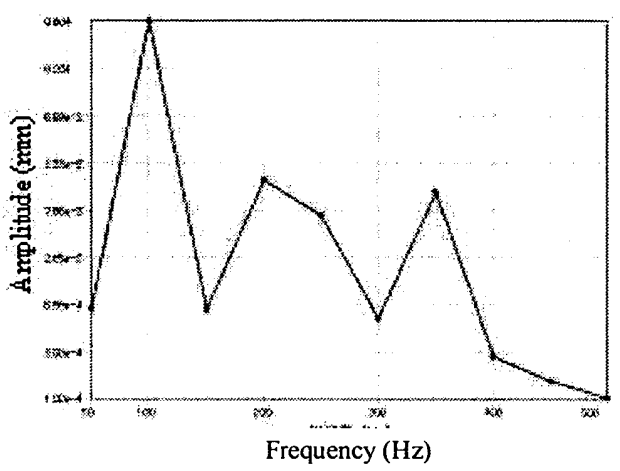

(D) Position D

Fig. 10 Analysis result 


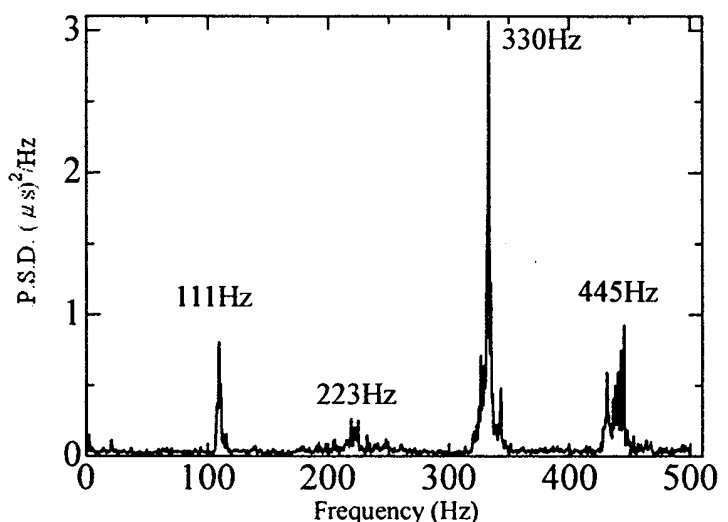

(A) Position A

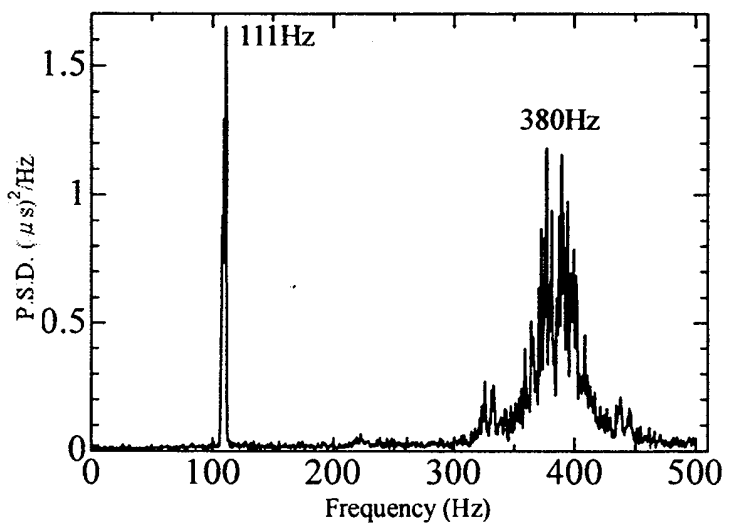

(B) Position B

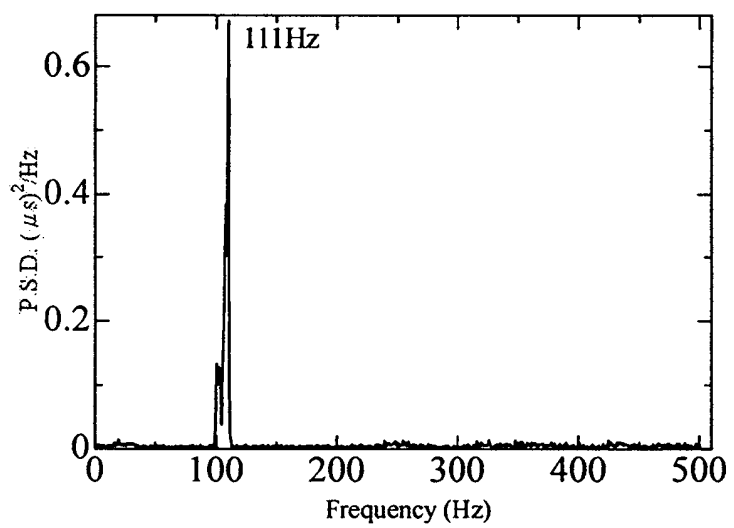

(C)Position C

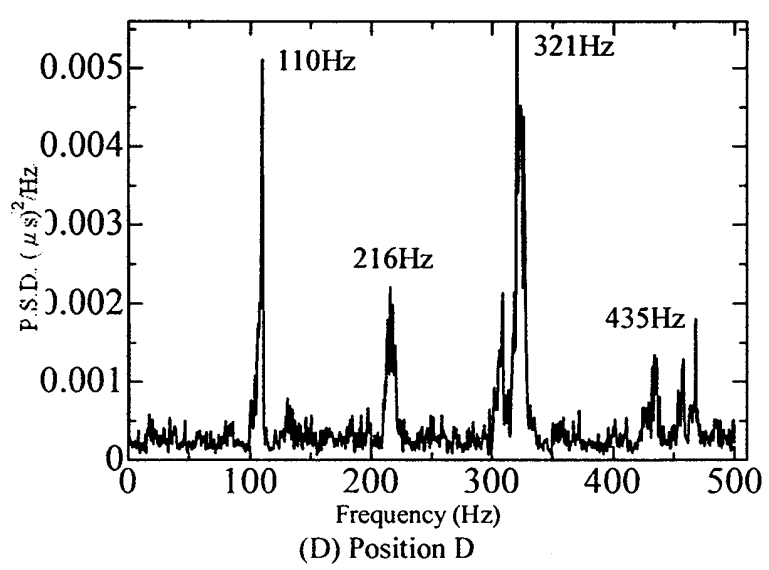

Fig. 11 Measurement result

\section{6. 桔言}

1） 3DCADにて鋼製型枠の解析モデルを作成した

2）生コンクリートを流し込んだ際に鋼製型枠に生じる圧 力を計算し, 解析を行った.

3）実験を行い，生コンクリートを流し込んだ際に鋼製型 枠に生じる相当応力と変位量の測定を行った.

4) 解析結果と実験結果はほぼ一致しており, 鋼製型枠の 解析モデルは有効であると思われる.

5) 解析モデルの有効性より，3DCAD・CAE を用いた解 析は、コンクリートを流し込んだ際に鋼製型枠に生じ る変位量・相当応力の状態を再現することができたと 言える.

6) 鋼製型枠の負担低減と軽量化を検討寸る場合，角パイ プを使用することは有効だと考えられる.

7）従来型枠と新構造型枠の解析結果の比較から, 新構造 型枠は変位量・相当応力の低減および重量 $20 \%$ 低減し ており，有効だと考えられる.

8）加振器の取り付け位置検討のために, 解析モデルを作 成し，周波数応答解析を行った。

9）解析の有効性を示すため, 型枠に伝わる周波数の測定 実験を行った。

10）測定結果と解析結果の比較から, 現在の加振時の周波 数は型枠の各部に良く伝わっており，現在の $120 \mathrm{~Hz}$ で の加振は有效な加振方法であることが分かった。

11）現在の加振器の位置は, 型枠の振動モードの腹部分で あり，振動が大きく伝達すると思われる.

\section{文献}

1) Tsumura $T$, Onishi $K$, The machine design drafting manual based on JIS, Rikogakusha Pubrishing Co.,Ltd., (1955)

2) Kadowaki $\mathrm{S}$, Three dimensional $\mathrm{CAD}$ by SolidWorks Jikkyo Pubrishing Co.,Ltd., (2008)

3) Kishi $S$, Kuriyama $H$, Date $M$, Illustration SolidWorks training-three-dimensional-CAD full master, Morikita Pubrishing Co.,Ltd., (2007) 